Chapter Six

\title{
Antiheroes in a Post-heroic Age: Sergei Dovlatov, Vladimir Makanin, and Cold War Malaise
}

\author{
I despise the word "we" \\ I hear in it the herd's lowing \\ The terrible silence of prison \\ And the thunder of the military parade. \\ Я ненавижу слово мы. \\ Я слышу в нем мычанье стада, \\ Безмолвье жуткое тюрьмы \\ И гром военного парада. \\ -Vladimir Korenatsky \\ In the dark twentieth century \\ With its clear sign of "Stalin" \\ If a man had a conscience, \\ He became a drunk. \\ В темном двадцатом веке \\ С четкой вывеской "Сталин" \\ Совесть была в человеке, \\ Если пьяницей стал он.
}

-Boris Slutsky

At the First Congress of Soviet Writers in 1934, Andrei Zhdanov had declared that "the whole life of our party, the whole life of our working class and its struggle combines the most stern and sober practical work with a supreme spirit of heroic deeds and magnificent future prospects." A directive had been handed down: documenting those "heroic deeds," those podvigi, and incarnating the heroes who performed them was the task of the official Soviet writer. As became clear in 1946, when Zhdanov presided over the purging of Anna Akhmatova and Mikhail Zoshchenko, there was no place in the Soviet Union for a nonofficial writer. This is what we have been examining in the preceding chapters: creating heroes was official policy.

What, then, happened to writers who refused to document heroic deeds? In many cases they "wrote for the long drawer," as the Russian saying goes; in some cases they published abroad, as did Voinovich, and in others they 
ceased to write at all. But living in the Soviet Union, they had to confront the discourse of podvig, the discourse of the heroic deed, on a daily basis-in the newspapers, in socialist realist fiction, at the movie theater, in their textbooks and their children's textbooks.

The generation of writers who came of age after World War II had to think about that heroic discourse, and about how their own fiction responded to it. These shestidesiatniki, "men (and women) of the sixties," had grown up on heroic narratives, whether of Civil War bravery demonstrated by Chapaev and other heroes, of "building socialism" - and the class warfare that entailed-one factory and kolkhoz novel at a time, or of partisans and frontline soldiers who defeated the evil Nazis and saved Europe from fascism. As children they also may have watched their neighbors and family members disappear into the Gulag. The terrors of their childhood-from Stalinism to the Second World War-had receded, but for many the taste of hypocrisy remained in their mouths.

Just a few years separated them from the myth of the happy Stalinist childhood; children born in the early to mid-1930s, in the view of one observer, frequently "managed to become dreamers." ${ }^{1}$ For example, author Galina Shcherbakova, born 1931, remembered her postwar mind-set in 1952, just before Stalin's death, thus:

Like everyone else, I lived under the impression of the Victory. It caused a kind of memory block. I forgot-even though I knew perfectly wellthat my grandfathers were murdered during collectivization and my uncles were killed in the bloody year of 1937. I became a patriot to the very bones, and everything in me squealed with joy at my wonderful homeland. ${ }^{2}$

After the death of Stalin, for Shcherbakova and many like her this patriotism and belief in capital- $V$ Victory-the transcendent meaning of Soviet victory in the Second World War-gradually began to disappear.

Many of those born in 1937 and later never reached that level of patriotism. Peter Vail and Alexander Genis argue that in the early 1960s, the "old heroes" of fiction (Pavel Korchagin, Alexander Matrosov, Alexei Stakhanov)—

1 See Lev Anninskii, “Struktura labarinta: Vladimir Makanin i literatura 'seredinnogo' cheloveka," Znamia 12 (1986): 220.

2 G. Shcherbakova, Iashkiny deti (Moscow: Eksmo, 2008), 241. 
dreamers, who believed in the Soviet future and lived within the discourse of podvig in an effort to make it come true-were due to be replaced with "new heroes." 3 But those who might have created the new heroes were not themselves believers; they were "quiet skeptics," "implacable anatomists." What kind of heroes would writers like those create? And was a protagonist necessarily a hero when the war was merely a "cold" one?

In this chapter we examine two authors, Sergei Dovlatov (1940-1990) and Vladimir Makanin (born 1937), themselves both "men of the '60s," to reveal the characteristics of what I call "antiheroism." These writers lived and wrote on the margins, had a phobia of the rhetoric of podvig, and adopted a tone of irony and even detached amusement. In this way they developed more fully the literary voice articulated by a previous generation, by Tvardovsky and especially Nekrasov. ${ }^{5}$

Dovlatov and Makanin were among a generation of writers who created characters perfect for their age, an age when only the truly deluded could believe any more in the grand Soviet experiment and when the Cold War too had become a stiff and stagnating fact of Soviet life. ${ }^{6}$ This post-heroic age was presided over, fittingly enough, by Leonid Brezhnev, who had been a commissar, not a frontline soldier or a commander, during World War II. Men and women of the '60s around the world experienced a decade of cultural and political upheaval; those in the Soviet Union were not part of that social revolution. In 1964, the year Brezhnev assumed power, the first Beatles album was released in the United States. Needless to say, it was not released in the Soviet Union. Four years later, the Soviets brought the Prague Spring to a hasty conclusion.

3 The critics discussed this in terms of "physicists" (i.e., scientists) and "lyricists" (i.e., humanists), terms that came from Boris Slutskii's 1959 poem of that name. See P. Vail', A. Genis, "Strana slov," Novyi mir 4 (1991): 239.

4 Anninskii describes Makanin this way ("Struktura labarinta," 226).

5 Mark Lipovetskii describes these two authors, among others, as having an "implicit existentialist orientation." See "Makanin's Existential Myth in the Nineties: 'Escape Hatch,' 'The Prisoner from the Caucasus,' and Underground,' in Byron Lindsey and Tatiana Spektor, Routes of Passage: Essays on the Fiction of Vladimir Makanin (Bloomington, IN: Slavica, 2007), 97.

6 For an extended exploration of this idea, see Alexei Yurchak, Everything Was Forever, Until It Was No More: The Last Soviet Generation (Princeton: Princeton University Press, 2006). Dovlatov and Makanin were a part of the "second-to-last" Soviet generation, but it may very well have seemed to them that the Brezhnev regime would last forever. 
Sergei Dovlatov-who was perhaps the antithesis of an official Soviet writer-chronicled dropouts and misfits, frequently drawing on autobiographical events to document the other side of the heroic Soviet coin. Dovlatov was a stylist par excellence, and he wrote and rewrote his anecdotes and observations about Russian life in numerous stories, tales, and essays. Never published as an author of fiction in the Soviet Union, Dovlatov emigrated to the United States in 1979, and only there did he begin to publish. His popularity in Russia since the early 1990s has created an almost cultlike following of readers and of Dovlatov-style writers, ${ }^{7}$ but through much of his life, Dovlatov was persona non grata in his homeland.

Vladimir Makanin's debut novel, A Straight Line (Priamaia liniia, 1965), was about a mathematician striving for good and justice. It was received positively by critics, who immediately ranked him with the "young writers" such as Vasily Aksyonov and Anatoly Gladilin. The issue of the literary journal Moskva in which A Straight Line was published also contained Bulgakov's long-awaited Master and Margarita and has been estimated to have been read by up to two million people. Reprinted a number of times, Makanin's novel remained popular and contributed to the wave of heroic literature of the Cold War, which featured scientists, engineers, and cosmonauts. ${ }^{8}$

After this splashy debut, Makanin describes his career in the seventies and eighties as akin to the experience of being buried in a pauper's grave: unable to publish in the literary journals, where his work would have been noticed, he published good books with provincial publishers. As he likes to say, no one read them, and they were promptly forgotten. ${ }^{9}$ This status of marginalized writer parallels the characters in his work, who are outsiders and dropouts from society in one way or another. After the collapse of the Soviet Union, Makanin's career revived. He won the Russian Booker Prize for his 1993 novella Baize-Covered Table with Decanter (Stol, pokrytyi suknom is grafinom poseredine), and his 1998 novel Underground, or a Hero of Our Time (Andegraund, ili geroi nashego vremeni) was an attempt to write the "big Rus-

7 Author Mikhail Veller, who like Dovlatov lived in Tallinn, Estonia, has built a reputation on being an "anti-Dovlatov."

8 See S. Iu. Motygin, Priamaia liniia? . . Evoliutsiia prozy V. S. Makanina (Astrakhan': Izd. Astrakhanskogo gos. ped. universiteta, 2001), esp. 4-39.

9 See Vladimir Makanin, "About Myself and my Contexts," in Lindsey and Spektor 19-20. Most of his books have since been republished, and in the 1990s he was the recipient of numerous literary prizes. 
sian novel" for the post-Soviet era. ${ }^{10}$ In both of these texts, Makanin explored the ways in which Soviet life warped the consciousness of his generation.

By the late 1960s and 1970s, participation in the military and in countless other militarized collective enterprises had become increasingly empty of any meaning for many Soviet citizens. Those aspects of Soviet life where attendance was obligatory-from school to army service to meetings to October Revolution parades and May Day demonstrations-were part and parcel of a collective spirit that now felt hypocritical. As poet Vladimir Korenatsky wrote in the poem we cite as the first epigraph to this chapter, thoughts of the "collective" for this generation triggered scenes of prison, military parades, and psychiatric incarceration. The word "we," so central to post-revolutionary and World War II discourse, now made the poet sick. He did not want to be part of the "herd."

Dovlatov and Makanin raised antiheroism to the level of an individual ethical choice. In their work they focused on the individual who reacts against the rhetoric of war, collectivism, and patriotism and tries to make his own small mark in reduced, ironic, subtle ways. Lev Anninsky has argued that for Makanin, the ethical vacuum of Soviet life did not appear to be a tragedy. "We're used to it! This is no catastrophe-this is life. The norm. No apocalypse." ${ }^{11}$ Byt. The norm. These are words in which some authors were able to find solace during the war but which in the postwar period became a betrayal of hopes and dreams. It seems to me, however, that Anninsky underestimated the bitter irony inherent in Makanin's approach to Soviet culture.

10 One of Makanin's other best-known stories is “The Caucasian Prisoner" (1994), in part because it seemed prescient, since it happened to be published just months before the onset of the first war in Chechnya. In that story, Makanin explored the "ambivalence of the idea of "imprisonment." See Alla Latynina, "Ne igra, a prognoz khudozhnika," Literaturnaia gazeta 7 (June 1995): 4. For criticism on Underground see, for example, Ivanova, "Sluchai Makanina," Znamia 4 (1997): 215-220; Konstantin Kustanovich, "A Hero of a Bygone Time, or Russian Literature as an Ecological System in Vladimir Makanin's Underground and Other Works," in Lindsey and Spektor, 115-128; Vladimir Bondarenko, "Vremia nadezhda," Zvezda 8 (1986): 184-194; Irina Rodnianskaia, "Neznakomye znakomtsy," Novyi Mir 8 (1986): 230-244; Anninskii, "Struktura labarinta," Znamia 12 (1986): 218-226; Aleksandr Agaev, "Istina i svoboda: Vladimir Makanin. Vzgliad iz 1990 goda," Literaturnoe obozrenie 9 (1990): 25-33; Mariia Levina-Parker, "Smert' geroia," Voprosy literatury 5 (1995): 63-78; Latynina, "Ne igra, a prognoz khudozhnika."

11 Anninskii, “Struktura labarinta," 225. 
For many, Makanin among them, the period of stagnation was tragic. The very fact that the underground emerged, that antiheroes tried to find their way in a society that failed to value them, created an irresolvable tension-between the "we" and the "I," the collective and the individual, the facts of life and the "truth" that they sensed was being betrayed. Makanin and Dovlatov, and others like them, sought the resolution in fiction, but rather than a solution, what they discovered for the most part was a means of distancing themselves from the norm. ${ }^{12}$

We can explore the shestidesiatniki in the seventies through Dovlatov's fiction, but with Makanin we will juxtapose two periods, his very early career and his post-Soviet fiction. In several early stories, we find a poignant depiction of postwar life, while in the post-perestroika novel Underground, or a Hero of Our Time he chronicled his own generation..$^{13}$ Makanin calls Underground a "memoir ... a requiem for the Russian Underground," which he describes as "a whole generation of ruined, talented people. Some became alcoholics, some committed suicide. Some became completely degraded. Most of them could not do any real work." ${ }^{14}$ The tragedy alluded to in Boris Slutsky's poem, quoted as the second epigraph to this chapter, was a real tragedy: conscience and sobriety were counterindicated in the age of Stalin, and even more so in the age of Brezhnev.

The ironic, matter-of-fact tone we find in these antiheroic authors was borrowed from Nekrasov and Tvardovsky, but their content was influenced enormously by Solzhenitsyn's One Day in the Life of Ivan Denisovich. For both Dovlatov and Makanin, the camps (and their reprisal in the second half of the twentieth century in the practice of psychiatric repression) represent the state's clear betrayal of its own citizens. Discussion of the Gulag in print opened the door for those considerations of the relationship between the individual and society which find full expression in their works.

The main characters of Dovlatov and Makanin's fiction push against Solzhenitsyn and Ivan Denisovich-a rank-and-file soldier turned Lagermensch-in order to present an antihero whose ironic worldview negates both socialist realism and the work ethic of the straightforward Solzhenitsyn.

12 See Kustanovich, who insists that "the dialectical struggle between preserving the ego and merging with the swarm usually has no resolution in Makanin's works." Kustanovich, "A Hero of a Bygone Time", 120.

13 Makanin's novella "Не and She” (“Он и Она," 1987) chronicles the unhappy lives of the shestidesiatniki, men and women of the 1960s.

14 Makanin, "About Myself ...," 23. 
Part of what was going on here was a keenly perceived generation gap. In talking about his favorite authors, Dovlatov had the following to say:

Aksyonov and Gladilin were the idols of our youth. Their heroes were our peers. I myself was a bit like Viktor Podgursky. ... Aksyonov and Gladilin were our personal writers. That is an inimitable sensation.... Then there were other idols. Sinyavsky. . . . Finally, Solzhenitsyn. . . . But they were already grownups. Sinyavsky was unreachable. Solzhenitsyn—even more so. ${ }^{15}$

Solzhenitsyn, after all, was some two decades older. Born in 1918, he lived through times that gave him the material he needed with which to create a hero, a peasant-hero who survived both war and Gulag. In fact, his own life was cast as one of the heroic artist, a survivor of war, Gulag, and even cancer. Makanin and Dovlatov, small children during the war, were never soldiers. And neither one could find anything heroic in Soviet life.

\section{Sergei Dovlatov: Life in the Zone}

War shaped Dovlatov in a very direct way. He was born in 1940 in the peripheral city of Ufa because his family had been evacuated there from Leningrad, then under Nazi siege, and after the war the family returned to a city marked by physical and psychological devastation.

As a writer, he does not easily fit into categories: a published journalist but a censored author, a "dissident" and emigre whose works published in America focused almost entirely on Soviet life and Soviet problems. In his fiction, Dovlatov documented heroic deeds, but he found them underground. In so doing, he incarnated unofficial Soviet antiheroes, confronting the problem of the socialist realist positive hero head-on.

Dovlatov matured both as a young man and an artist during the cultural thaw of the early 1960s. That space briefly allowed writers to ask questions about how an individual should act within the collective, about the individual's interactions with the state, about how the "I" negotiated with the "we." But it also gave birth to new ideas of how individuals could live honestly and

15 Dovlatov, Maloizvestnyi Dovlatov (St. Petersburg: Zhurnal “Zvezda," 1995), 244. Later in emigration, Dovlatov was to reflect that Solzhenitsyn had "begun with earthshaking novels" ("Blesk i nishcheta russkoi literatury," in Igor' Sukhikh, Sergei Dovlatov: Vremia, mesto, sud'ba [St. Petersburg: Kul't-inform-press, 1996], 298), implying that his later work did not have as great an impact on Dovlatov and his contemporaries. 
ethically within a society devoted to heroics and the hero. Dovlatov explored and developed these ideas especially in his first two fictional works, The Compromise (Kompromiss) and The Zone (Zona). ${ }^{16}$

Khrushchev's thaw really did seem to promise a new beginning. As Dovlatov described it, writing in New York in 1982:

On the pages of the journals the names of talented young writers shone: Aksyonov, Gladilin, Voinovich, Okudzhava, Efimov, Akhmadulina, Shukshin, Iskander, Balter, and many others. This was a time of great illusions, enormous hopes. It seemed to many that the literary process could be renewed, that bridges could be built from classical Russian literature to the healthy artistic tendencies of the beginning of the sixties.

Dovlatov was a teenager at this time, and a young man when the Thaw ended. That hopefulness and subsequent disappointment constituted a formative experience for the writer. Looking back on the period from his forties, he continued:

But alas, these illusions were not to come to fruition. The official process of the democratization of society quickly ran into a dead end, and what came to replace it was stunning in its even greater poverty, infertility, and boredom.

If under Stalin talented writers were first published, then covered in filth in print, and finally shot or destroyed in the camps (Babel, Pilnyak, Mandel'shtam), now no one was shot, almost no one was put in prison, but no one was published. The best writers, making like conspirators, wrote, as they say, "for the drawer," and those less honest, trustworthy, and truthful served the government, receiving in turn access to very tempting material goods. ${ }^{17}$

That process gave birth to Dovlatov's idea of the "compromise" - the tacit agreement of the Soviet citizen to live and work in his homeland, an agreement that gradually ate away at the individual and his soul, turning him into a lackey of the state. The health of the state was not conducive to the mental health of the individual writer.

\footnotetext{
16 All quotes from Zona and Kompromiss in volume 1 of Sergei Dovlatov, Sobranie prozy $v$ trekh tomakh (St. Petersburg: Limbus-Press, 1993), 25-172 and 173-324.

17 "Blesk i nishcheta," 300-301.
} 
Like Solzhenitsyn and his contemporaries Varlam Shalamov and Evgeniia Ginzburg, Dovlatov contributed to the literature of the Gulag, the literature describing life in what Russians call the Zone-a widespread Soviet nickname for what Solzhenitsyn termed the "Gulag Archipelago," the system of prison camps that dotted the landscape of the Soviet Union. But the other three writers were in direct conflict with the state when they were imprisoned, and directly benefitted from official permission when they published works about their experience. Their understanding of the Gulag was political and personal. In contrast, Dovlatov belonged to a completely different generation, and as Ilya Serman - another victim of Stalin's camps-has pointed out, Dovlatov's prison camp was also completely different. ${ }^{18}$ Not imprisoned themselves, Dovlatov's generation understood the idea of Lagermensch metaphorically.

Even so, the Gulag loomed in the Soviet imagination in the 1960s and beyond. In an essay entitled "The Gulag as Civilization," Andrei Bitov has argued that "with time, between the zones freedom evaporated like water; the straits became parched, and it all became one zone. [...] whatever reality you take, you can describe it as a prison camp. [...] the prison camp is the very model of our world." ${ }^{19}$ The Zone was a real place, but it also became a metaphor for life in the Soviet Union. The narrator of Dovlatov's novel The Zone would have agreed with Bitov. He claimed, "There is a suspicious similarity between guards and prisoners. Or even more broadly, between 'prison camp' and 'freedom."' 20

Dovlatov's biography forms a mirror image of the fictional Ivan Denisovich's life in the Gulag. Ivan was a World War II soldier turned prisoner, arrested for imagined crimes against the state, while Dovlatov fulfilled his military service to the Soviet state as a prison guard in the camps. But during his service, Dovlatov did not feel part of a grand project launched by the collective against enemies of the state; rather, as a guard he felt as powerless as the prisoners he guarded. ${ }^{21}$

Basing his stories in The Zone on his own experience, Dovlatov deliberately blurred the boundaries between this world and the Soviet world

\footnotetext{
18 “Teatr Sergeia Dovlatova," Grani 136 (1985): 138-162.

19 Andrei Bitov, “Gulag kak tsivilizatsiia," Zvezda 5 (1997): 6.

20 Dovlatov, Zona, 26.

21 See Mark Lipovetskii, “Uchites', tvari, kak zhit” (paranoiia, zona i literaturnyi kontekst)," Znamia 5 (1997): 199-212. Lipovetsky argues that for Shalamov and Solzhenitsyn, the zone is primarily a time-space of violence, while for Dovlatov it is an example of the absurd as a universal principle (“Uchites'," 209).
} 
surrounding it, revelling in the metonymic shift that suggested the Soviet Union was also a Zone, a prison camp on a larger scale. As late as 1997, Bitov continued to assert that he personally had not yet left the Zone-in other words, his worldview and psychological makeup remained that of a prisoner long after the walls came down. Many Soviet and post-Soviet citizens have experienced something similar.

Dovlatov's hero in his autobiographical narratives does not fulfill the category of positive hero according to the doctrine of socialist realism. But this understated, picaresque hero-the antihero-is still Soviet. His definition of "svoi" ties his Soviet hero back to the nineteenth century: "[Alexander] Herzen was 'our kind,' a down-to-earth and precise person, . . . intelligent and honorable."22 These were the qualities that characterized the antihero of Dovlatov's generation: a dissident, "outsider" antihero, who deflates the very Soviet discourse within which he lives, helping us to measure the meaning of heroic for a post-heroic age.

\section{What Is a Hero If There Is No Truth: Dovlatov's The Zone and The Compromise}

In his "Soviet" works, specifically The Zone (1982) and The Compromise (1978, published 1981), Dovlatov highlighted the hypocrisy of life in the Soviet Union. Each of these narratives has a structure complicated by the presence of one or more autobiographical heroes. ${ }^{23}$ In The Zone, for example, on the level of plot Dovlatov exploited the complexities of life in a totalitarian society, and he also did so on the level of the construction of the text. In his narrative, the reader sees that not just content but form was affected by Soviet conditions.

Dovlatov complained that his manuscript seemed fragmentary because it was fragmentary-having had to be smuggled out of the Soviet Union by

22 As a young man conducting an epistolary courtship, Dovlatov made a list of books he thought the future actress Tamara Urzhumova should read-which would also show her what kind of books he liked. He started with Russians: "If you haven't read it, you should definitely take up Herzen, My Past and Thoughts. You will be surprised to what extent Herzen was 'our kind' ['svoi'], a down-to-earth and precise person, to what extent he was intelligent and honorable. No need to read his fiction. It is very disappointing." Dovlatov, Letter to Tamara Urzhumova, 1 July 1963, published in Zvezda 8 (2000): 140-142.

23 Karen Ryan succinctly characterizes The Zone as featuring a "relatively complex narrative strategy" (Contemporary Russian Satire, [Cambridge: Cambridge University Press, 1995], 180). 
well-meaning Frenchwomen in small microfilmed excerpts. Dovlatov left it up to the reader to imagine the connotations here. Further, he undercut these "Soviet" complaints by adding others unrelated to Soviet conditions. In the capitalist "free" country where he finally published the manuscript, neither publishers nor the public really cared about his collection of camp stories, and his ability to assemble the manuscript was further hampered by technical details, such as the need to rent a photo enlarger.

The Zone itself incorporated all these complaints and more, becoming a doubled chronicle of writing and self-discovery in Soviet Russia and publishing and reflection in the United States. As such, The Zone owes much to the genres of epistolary novels, story cycles, and autobiographical fiction. ${ }^{24}$ Allegedly first written in the mid-1960s, the final published book became a completely different work thanks to the letters added to the text on publication in 1982. ${ }^{25}$ This technique, of co-creating a narrative space between two very different times (1960s and 1980s), two very different places (a Soviet prison camp and New York City), and two necessarily different narrative voices (a prison guard and an emigre to America), may very well be unique to Dovlatov and to this work in particular.

Since his subject matter, Soviet prison camps, had by the time of publication been vividly and indelibly illustrated by both Solzhenitsyn and Shalamov, Dovlatov was in a sense forced to compete with his predecessors, as he himself acknowledged in the text. Through innovations in narrative voice as well as through generic play, Dovlatov told his story of life in, and escape from, the Zone of the Soviet Union.

In contrast, The Compromise retells Dovlatov's experiences as a journalist in Estonia in 1972-1975. Again, part "document," part fictionalized memoir,

24 This technique is reminiscent of what Galya Diment described in her book The Autobiographical Novel of Co-Consciousness: Goncharov, Woolf, Joyce (Gainesville: University of Florida Press, 1994).

25 In fact, one of the reasons Dovlatov went to Estonia in 1972 was to try and publish The Zone. Notes of a Camp Guard, which was accepted by a publisher in Tallinn, as the conditions of censorship there were less strict than in the "centers" of Leningrad and Moscow. However, although The Zone reached the stage of page proofs, in the end it was banned. This story becomes a part of the text of The Compromise, thus linking the two works and strengthening the autobiographical background of the Estonian novella. For more on this, see Jekaterina Young, "Dovlatov's Compromise: Journalism, Fiction and Documentary," Slavonica 2 (2000): 44-67 as well as her book, Sergei Dovlatov and his Narrative Masks (Evanston: Northwestern University Press, 2009), chapter 4 . 
the novel presents a series of so-called "compromises" that defined life for Dovlatov in the Soviet Union. His autobiographical character works for the newspaper Soviet Estonia-a "party newspaper." The overt conflict of the work is between what the journalist publishes in the paper and the "back-story", the events and people who are transformed by Soviet journalistic convention into the somewhat mundane narratives that pass muster for print.

Divided into an introduction and twelve chapters, the novel ostensibly investigates the relationship between Soviet print media and "reality." Each chapter includes a news item (complete with dateline and headline) and a second narrative, often rich with dialogue.

In the pages of The Compromise, Dovlatov delineated his own moral categories of right and wrong, truth and falsehood, exploring totalitarian mythmaking from the inside, from within Soviet journalism. As Andrei Ar'ev has written, "Sergei Dovlatov valued truthful invention over the truth of fact." A journalist observing not the mud and blood of war but the workings of the Socialist state on the kolkhoz and in the city, Dovlatov refused to believe in facts as such. Instead, he saw that everything was relative.

Accused by his fictional editor of "political nearsightedness" and "moral infantilism" in the first compromise, i.e., the first chapter of the novel, Dovlatov dismissed the charges as unimportant. After all, he claimed, he was not writing for the newspaper in order to exercise his creative mind, or indeed to further the goals of the Communist Party, but rather to earn a living. "They paid me two rubles for the notice. I'd hoped it would be three..." In this work, a send-up of journalism, Dovlatov pretended that writing for a newspaper can be a simple cash exchange. But in fact, he had a conscience, and as Slutsky so poignantly put it, the only alternative for a man with a conscience in Soviet society was to become a drunk.

Dovlatov described his editor as an "oily, marzipanish man, a kind of reserved rascal," and this scared and angry Soviet bureaucrat presented a clear antagonist for the journalist. ${ }^{27}$ Editors generally fall into this category"them" and not "us," "chuzhoi" and not "svoi." One editor, trying to teach

26 Andrei Ar'ev, introduction, "Sergei Dovlatov: Deviat' pisem Tamare Urzhumovoi," Zvezda 8 (2000): 137.

27 Dovlatov, Sobranie prozy, 1: 177. Turonok is not the total hack he purports to be; it is important to Dovlatov that despite everything, the journalist's talent is recognized. Turonok sends Dovlatov on assignment because, much as he hates to admit it, and much as he recognizes Dovlatov's ideological unreliability, he also knows that Dovlatov can write and the other journalists working for him are decidedly mediocre. 
Dovlatov the rules of Socialist journalism, explained, "All your characters are scoundrels. If your hero has to be a scoundrel, then you should bring him to a moral crisis through the logic of the story. Or to retribution. But in your work scoundrels are something natural, like rain or snow. ..." (Sobranie prozy, 1: 182).

These scoundrels were precisely the antiheroes whom Dovlatov championed. In a kind of artistic manifesto, Dovlatov explained his attitude toward the concept of the heroic: "In this story there are no angels and no villains.... No sinners and no saints. And there are none in life, either. [...] I'm not certain that in life repentance invariably follows crime, or that feats are rewarded by bliss. We are what we feel. Our traits, merits and sins are brought into the world by close contact with life. ..."28

"No sinners and no saints." "We are what we feel." "I'm not certain that ... feats are rewarded by bliss." These phrases represented Dovlatov's stance as a bytopisatel', an existential writer of the everyday, who resisted the rhetoric of podvig with all of his being. Writing in the era of stagnation, with Cold War repercussions all around, facilitated this stance.

As he struggled to define his characters-in The Compromise, represented by fictional versions of himself and his friends-he wrote against any remnants of the socialist realist positive hero, searching out other categories of good and evil, to finally define a new kind of hero in a post-heroic world, an antihero who also has a right to live and to love. Not only did Dovlatov question the moral categories offered by official Soviet literary doctrine and Communist upbringing, he even doubted-and perhaps mourned, in a way-the clear moral imperatives of nineteenth-century fiction. For Dostoevsky, it was unquestionable that crime had to have punishment, and indeed "repentance" - without moral regeneration Dostoevsky's Raskolnikov could not have experienced the rebirth that comes to him in his Siberian exile. That is one trajectory of heroism.

For Dovlatov, though, everything was more ambiguous. He and his friends were drawn together by "a slight distaste for the official side of

Dovlatov is the "lyricist" Turonok needs for certain assignments where "the human element" (chelovechinka) is required.

28 Dovlatov, Sobranie prozy, 1: 182. This section trails off with the characteristic: "Nature, you are my goddess!' And so on ... Well, anyway ..." Dovlatov's dislike of purple prose keeps his ironic tools sharp. Literary and moral musings are too rhetorically overheated for him. 
newspaper work [and] a certain healthy cynicism, which helped us avoid fine-sounding words. ..." (Sobranie prozy, 1: 182). Perhaps ironically, it was a lack of discipline on the "ideological front" that had gotten the Dovlatov character fired from his previous job, in Leningrad. And in a work devoted to the continual compromises of life under the Soviet regime, it was hypocrisy that pushed Dovlatov over the edge. In journalism, he explained:

Everyone could do one thing. Violate the principles of Socialist morality in one area. That is to say, one person was allowed to drink. Anotherto play the hooligan. A third-to tell political jokes. A fourth-to be Jewish. A fifth-to not belong to the Party. A sixth-to lead an amoral life. And so on. But each person, I repeat, was allowed one thing. It was not possible to be both Jewish and a drunk. A hooligan and a nonparty member. ... I myself was fatally universal. That is to say, I allowed myself everything in small doses. I drank, behaved scandalously, showed ideological nearsightedness. In addition, I was not a Party member, and I was even somewhat Jewish. Finally, my personal life was becoming more and more complicated. ${ }^{29}$

In refusing to follow the unwritten rules of Socialist life and morality-and indeed lampooning them as ridiculously arbitrary-Dovlatov pushed against the official line. When at a party meeting at his Leningrad newspaper it was suggested he "go to the people" and write about "real life," Dovlatov burst out, "[If I gave you] real life you would shoot me without a trial!" It was this refusal to sign on to official hypocrisy in Leningrad that led to Dovlatov's move to Estonia.

Dovlatov's greatest antihero in The Compromise is the unconquerable Ernest Leopoldovich Bush, an anarchist who despite his best efforts to join in state activities always undermines himself in the end, ruining his chances for jobs, apartments, and promotions. When Dovlatov's alter ego in "The Ninth Compromise" asks, "Who is Bush?" his friend Shablinsky replies, "Bush is something fantastic. You'll see. I think you'll like him." ${ }^{30}$ That shine and that breadth (blesk, razmakh) are the qualities that best characterize the individualist, who in the final account is glad to have dropped out of society-and

29 Dovlatov, Sobranie prozy, 1: 269. Dovlatov's mother was Armenian and his father was Jewish. His personal life was indeed complicated: married three times, he had four children with three different women. 
who in Dovlatov's fictional world usually gets the girl, the vodka, and the reader's admiration as he does so.

But the autobiographical Dovlatov character in these stories cannot come to terms with life as an outsider. At one point in the narrative, Dovlatov and his friend Mikhail Zhbankov-a photojournalist and confirmed alcoholic fifteen years Dovlatov's senior, and thus fifteen years further along in his cynicism, and his alcoholism-are sent to the Estonian countryside to prepare a story on a true Socialist heroine, a Stakhanovite milkmaid, which is funny, almost absurd, just on its face, although of course a common theme in the Soviet press.

Met at the train station by the Regional Party Committee secretary, Dovlatov and Zhbankov are taken to a government dacha, where they are coddled, wined, and dined by two women, the thirty-year-old representative of the regional Komsomol and her younger colleague, supposedly an aspiring young journalist. Mostly-as is often true in what might be called the "alcoholic chronotope" of Dovlatov's fiction-they are wined.

Over the course of his assignment, Dovlatov is unable to enjoy the charms of the young Evi Sakson. ${ }^{31}$ Instead the journalist is tormented by that eternal Russian question, inherited from Chernyshevsky via Lenin: "What is to be done?" Zhbankov tells Dovlatov, "Don't think. Drink vodka." Evi concurs, in her Estonian-accented, amusingly halting Russian, but she has other ideas for how Dovlatov should spend his time not thinking: "You should think less. Enjoy the good that exists. [. . . That's enough drinking. Let's go. I'll make you like me. [. . .] Don't think. Sometimes it's better to be stupid." "Too late," Dovlatov answers, "I'll have to drink" (Sobranie prozy, 1: 256-257). Unable to avoid contemplation of his wasted life, focused on the bitter truth that "there's only one life, there won't be another," Dovlatov drinks himself into oblivion.

Regional Party Committee Secretary Liivak, whose first allegiance is to party discipline, offers a stark contrast with the anti-authoritarian Dovlatov. When Liivak commends Dovlatov for his work in the provinces, he delivers an utterly standard and banal speech: "Comrades, I am satisfied. You worked well, enjoyed some cultured leisure time. I was pleased to meet you. I hope

31 Evi is female company specifically provided for him by the party secretary. Konstantin Kustanovich has explored this ritual-of providing sexual partners for visitors-in his essay "Erotic Glasnost: Sexuality in Recent Russian Literature," World Literature Today 67.1 (Winter 1993): 136-144. See 138. 
that our friendship will become a tradition. After all, party workers and journalists are in a way, I would say, colleagues. I wish you success on the difficult ideological frontlines. Perhaps you have a question?" (Sobranie prozy, 1: 259). The hypocrisy is stunning, but the military context is equally striking: Liivak assumes that these journalists are working hand in hand with Communist party hacks in the struggle for Cold War domination over the West.

Dovlatov and Zhbankov have been anything but good workers or cultured tourists; they have spent their entire business trip drinking heavily. The short letter that Dovlatov produced in five minutes on the morning after was barely literate: "Dear and Much Respected Leonid Ilich! I would like to share with you a happy event. In the last year I managed to reach unheard of work results." Double entendres also permeated the text of the telegram: "And one more happy event occurred in my life. The communists of our farm have united to choose me as their member!"32 Dovlatov's ghostwritten telegram to Brezhnev, penned with a shaking hand, was published in the newspaper along with Brezhnev's reply to the prizewinning Estonian milkmaid-received before the telegram was written. The ritualistic nature and ultimate insignificance of the entire assignment both justifies and causes the drunkenness of the journalist. Conscience and sobriety are two incompatible concepts.

In answer to Liivak's query, "Perhaps you have a question?" Zhbankov articulates the only question the two Tallinn journalists can imagine, their existential answer to the thought that their work had brought them into such close contact with party hacks and political idealogues: "Where's the bar?" ("Gde bufet?") The uncomplicated Evi Sakson, bidding Dovlatov good-bye at the station, reminds him, "Don't drink so much ... or else you can't make sex" (Sobranie prozy, 1: 259, 260).

All of these characters demonstrate the boundaries of Dovlatov's own moral strictures. Willing to take a business trip to help prop up the ideological underpinnings of the Brezhnev regime, the journalist can only stomach his assignment by drinking heavily. Aware that he is too clever to hoodwink himself about the meaning of his own work, Dovlatov chooses to drown his sorrows (and perhaps his intellect) at the party-provided provincial dacha. The open corruption of the party system, with sexual and alcoholic favors

32 Dovlatov, Sobranie prozy, 1: 258-259. As he comments, "Here the style was clearly shaky, but I hadn't the strength to correct it" (1:259). 
guaranteed, forms the backdrop for the hero's despair; his linguistic and professional accomplishments are utterly pointless, for Brezhnev's telegram would arrive with or without Dovlatov's service as a ghostwriter. But unlike Ernst Leopoldovich Bush, he cannot drop out but remains on the margins of the system: drunk and without the girl.

The autobiographical hero in The Compromise is obviously no hero, in any traditional sense, at all. He is nothing like the hardworking peasant-prisoner protagonist of Solzhenitsyn's One Day in the Life of Ivan Denisovich from two decades earlier. But the reader recognizes the difficulties the journalist faces. His faults-drinking, amorality, being "somewhat Jewish" - stem from his intellect, his hatred of hypocrisy, his search for the truth and for individual integrity in a society that denies him even that much. As he articulates the problem to a friend, "Under our conditions, it's more worthy to lose than to win."

There could not be a starker indictment of the rhetoric of podvig. In the post-heroic age of Brezhnev, Dovlatov's antihero exhibits many admirable characteristics, among them his particular brand of honesty and foolish bravery. These traits in turn complicate his life and keep him from being able to bridge the gap between the official Socialist "what is to be done" and his own cynical experience. In a common-enough response for the dissident hero of the 1970s and '80s, instead of the reaction, "I should drink less," Dovlatov's hero determines, "I should drink more." Not "pit' nado men'she," but "pit' nado bol'she." ${ }^{33}$

Dovlatov's antihero in the 1970s is the man behind the media, working within the dishonest discourse of Soviet journalism to support the by-now stagnant Soviet regime. Though the newspaper snippets of The Compromise suggest that the journalist writes what he must to receive his pay, continuing to help manipulate popular opinion, he exists in such a disillusioned time that neither he nor his readers subscribe to the nonsense he publishes in Soviet Estonia. Yet in his self-deprecating, ironic way, Dovlatov creates a hero the reader can believe in, even if we don't believe in his enterprise of propping up the Soviet regime. Dovlatov's hero did not accomplish great feats, but neither did Brezhnev. Dovlatov's alcoholic, amoral journalist represents an antihero

33 Compare to the hero of the popular 1975 Soviet film The Irony of Fate (Ironiia sud'by [dir. Eldar Ryazanov]). This statement also begs comparison with Venedikt Erofeev and his famous alcoholic narrative. On Moskva-Petushki see especially Ryan, Contemporary Russian Satire, 58-100. 
living in hypocritical times, and he finds his dignity not in labor or in podvig, as a socialist realist hero should, but in irony and at the bottom of a bottle.

In his work, Dovlatov asserted that "there are no angels and no villains. ... No sinners and no saints. I long ago ceased to categorize people as positive or negative." And, he concluded, "or literary characters either." Not agreeing to the rules of the game-whether the propaganda game, the socialist realism game, or the party game-represented a certain line in the sand for Dovlatov, but he, and his antiheroes, played anyway, understanding that losing is itself a protest and in that sense a kind of winning.

The Compromise began with Dovlatov, unemployed, looking through his portfolio of newspaper clippings: "Yellowed pages. Ten years of lies and pretense. But still, here are people, conversations, feelings, reality. . . Not in the pages themselves, but beyond, on the horizon... The path from pravda to istina is a difficult one" (Sobranie prozy, 1: 176).

Pravda is of course truth, but so is istina. Dovlatov here was playing with untranslatable words; istina is generally speaking more "true" than pravda, but in the Soviet period, when pravda was contaminated, claimed as its own by the Communist Party through their party organ, the newspaper of that name, istina could be even more difficult to find.

We have been looking at this question of truth and fact throughout the Soviet period. Truth is what gives meaning to fact; details fill it out to portray the experiences of war and peace. But postwar Soviet society was so permeated by hypocrisy, by "compromise," that Dovlatov and his generation struggled to address the question under new circumstances.

This fungible concept of truth undergirds The Compromise. When is it permissible to lie? When should one tell the whole truth? What do those truths mean in a society permeated by lies? And finally, what is a hero if there is no truth?

\section{Individual vs. Collective-I vs. We: Makanin's Protest}

Vladimir Makanin describes the 1960s as a time when the whole idea of the individual (Lichnost') had passed. His first novel, A Straight Line, was in his words about "an unsuccessful Individual who could not survive in the twentieth century when everything was being worked out by collectives." ${ }^{34}$ This theme-the theme of the individual trying to live in a collective cul-

34 "A Conversation with Vladimir Makanin," in Lindsey and Spektor, Routes of Passage, 175. 
ture-became central to Makanin's work. Mary Ann Szporluk identifies this as Makanin's protest against socialist realism and Soviet society. She writes:

The politically correct writer was expected to give the reader moral guidance and correct social and political interpretations. According to the Bolshevik adaptation of Marxist theory, the Soviet Union would evolve into a perfect social system in which the individual would be subordinated to the collective. Makanin responded to this all-too-real cultural pressure by making the repression of the individual in the collective culture one of his major themes. He examines the effects of collective thinking on the individual as well as the responsibilities of individuals to society. ${ }^{35}$

Makanin's personal history gave him private lessons in the tensions of individual versus collective and the ironies that often resulted from that friction. After World War II, his father-as if in a parody of Gladkov's plot from Cement-was attempting to make repairs at the plant where he worked and was instead arrested for sabotage. Makanin's uncle came to the rescue: he "donned his patriotic medals, took his civil war gun, and went to the Orsk prosecutor's office to demand his brother's release." ${ }^{36}$ The power of the war hero in this case worked, and Makanin's father was let go, but his son learned an important lesson: that socialist realism as featured in Cement was a fiction. The lone worker cannot put the factory back on line, and by isolating himself he becomes extremely vulnerable to the repressions of the state. Makanin's success as a chess wunderkind singled him out as an individual who could dominate in an intellectual game; his father's arrest in 1948 taught him the dangers of being singled out.

This dislike of the collective characterizes Makanin's entire literary career. In his assessment of Makanin some years ago, Deming Brown pointed out that Makanin had been identified with a number of literary trends-the "forty-year-olds," "city prose," and the "Moscow school" - and had been considered both an heir to the "confessional prose" of the 1960s and a kinsman of "village prose." ${ }^{37}$ In fact he belongs to no school. Makanin's work varies from stories of life in the Urals to allegorical tales of dystopia. In all his fiction, the

35 "Afterword," in Vladimir Makanin, Escape Hatch and the Long Road Ahead. Two Novellas (Ardis: Dana Point, 1996), 186.

36 Recounted in Lindsey, "Translator's Preface," from Makanin's memories, x.

37 The Last Years of Soviet Russian Literature: Prose Fiction 1975-1991 (Cambridge: Cambridge University Press, 1993), 102. 
protagonist finds himself alienated from collective enterprises, suffering from attempting to fit in, or otherwise lost in the society that surrounds him.

The dislocations of postwar reconstruction featured prominently in his early novellas Fatherlessness and The Soldier and the Soldier's Wife, both from $1971 .^{38}$ The first is an urban narrative that centers around a group of children who grew up in an orphanage since "their fathers remained in the trenches," i.e., perished during the war, leaving them both homeless and fatherless. Fatherlessness is a wonderful group portrait of lost boys, not heroes as in Libedinsky's optimistic novel Birth of a Hero, but young men searching for meaning and purpose in life.

The second novella features two individuals in a village: a woman whose fiancé did not return from the war-a "Russian soldier's wife, a Russian Penelope, who sat and waited" - and a married soldier who longs for the "speed, the intensity of military life" and who cannot find his way in peacetime (Makanin 154, 205). In an ironic twist, demobilized soldier Ivan Semenych starts an affair with Katya and insists that she procure wild ducks from the market to provide legitimacy for his cover story that he spent the night hunting.

When Katya is desperate because she cannot obtain the duck, a helpful driver assumes it is for her sick child: "He could just see it: somewhere a child is dying, the country doctor is useless, and a special bouillon, made from wild duck, was essential [to save the child from death]" (Makanin 175-176). Thus the childless woman uses a stranger's humane assumption to cover for her irresponsible lover. ${ }^{39}$ In the end, the protagonists of this story find themselves alone and hopeless, utterly lacking a connection to the social and cultural life around them and as a result lacking any ethical grounding.

This lost feeling is common among Makanin's characters and is accompanied by an absence of personal and collective responsibility. One critic describes this as a trait of the "barracks" lifestyle in the Soviet Union: "I didn't think it up, so I can't change it; if they're giving, take, if they're beating you, run; that's how things are, you just have to fit in." ${ }^{40}$ Militarized life was unsustainable, especially in the absence of war.

38 Makanin, Bezotsovshchina. Soldat i soldatka. Povesti (Moscow: Sovetskii pisatel', 1971).

39 This wild duck motif appears in a tragic form in Viktor Astafiev's late story "A Bird of Passage," where in the postwar period a real child is dying of starvation, but even the duck bouillon cannot save him.

40 Anninskii, "Struktura labarinta," 220. 
Rather than maintaining a patriotic spirit, Soviet citizens began to avoid responsibility. This "adaptation" to life and to the unchanging situation of the Brezhnev stagnation (what Yurchak has called, "Everything was forever until it was no more") represents perfectly the refusal of a whole generation of Russians to believe in the hopelessly corrupt system that surrounded them and clarifies a kind of "keep your head down" attitude that ran counter to the official rhetoric of podvig and in the end contributed to the system's failure. Brezhnev followed on Stalin's 1946 insistence that the Soviet Union would always be at war with the capitalist West, but already at the beginning of his era people had ceased to believe that this war could be won, or even that it was being fought at all effectively.

\section{War, and Gulag, Updated:}

\section{Soviet Punitive Psychiatry in Underground, or a Hero of Our Time}

For Makanin, the psychiatric asylum represents the logical extension of what a permanently militarized nation would do to its citizens. If life in the army imposed order, discipline, and regimentation on the population, that life also held out the possibility of heroic validation. If life in the Gulag removed troublesome individuals from the body of the nation, the camps still provided hope for camaraderie and individual resistance. Diagnosing individuals as mentally ill removed them physically not only from the rest of Soviet society but, in a sense, from the human race as well. This was Soviet policy.

The use of psychiatry as part of the apparatus of an oppressive state was formalized in 1959, when Nikita Khrushchev defined any kind of dissent or social deviation as a mental illness. Quoted in Pravda as saying that "a crime is a deviation from the generally recognized standards of behavior, frequently caused by mental disorder," ${ }^{31}$ Khrushchev gave carte blanche to psychiatric panels working under the aegis of the KGB to diagnose, hospitalize and isolate, and frequently to engage in medical torture.

Under Brezhnev the use of mental institutions took a particularly cynical turn. Among other things, during these years the psychiatric hospital was

41 Pravda, May 24, 1959, cited in Cornelia Mee, Internment of Soviet Dissenters in Mental Hospitals (Cambridge, Eng., 1971), 1. There is some evidence that the diagnosis "creeping schizophrenia" was invented in response to Khrushchev's idea that only a madman could be critical of the Socialist system. See George Windholz, "Soviet Psychiatrists under Stalinist Duress: The Design for a 'New Soviet Psychiatry' and its Demise," History of Psychiatry, vol. X (1999): 329-347, 344. 
used as a part of a public relations campaign. While prisons and camps might make for bad press in the West, a therapeutic institution like an asylum might bring good press. As Zhores Medvedev, a victim of forced committal in 1970, reasoned:

Someone had the simple idea that the increasing number of trials and political prisoners made a very poor public impression, while an increase in the number of patients under treatment in hospitals would be a very good indication of social progress. From this moment, psychiatric hospitals began to expand. ${ }^{42}$

Schizophrenia, or split personality, was far and away the most common diagnosis made by Soviet psychiatrists, particularly in the Brezhnev era, and therefore the medical rationale usually given out for the incarceration of patients during the most intense period of punitive psychiatric practice. ${ }^{43}$ As Teresa Smith has argued, the Soviet case was unusual, particularly because of the large number of individuals involved in various dissident movements and subsequently subjected to psychiatric evaluation and incarceration. Soviet psychiatry came to serve the interests of the repressive state thanks to a set of circumstances which Smith explores, most importantly the "unusually ambiguous definition of mental disease." ${ }^{4}$ The Soviet definition of schizophrenia was so expansive that it came to include an "asymptomatic form," in which doctors argued that "outwardly well-adjusted behavior, formally coherent utterances, and retainment of former knowledge and manners [are] characteristic of a pathological development of the personality." ${ }^{35}$ Thus so-called "normal behavior" could actually be used to indicate the presence

42 Roy and Zhores Medvedev, A Question of Madness (London: Macmillan, 1971), 200. Incidentally, the PR campaign did not work, and the World Psychiatric Association censured the Soviet psychiatric organization for the use of repressive psychiatric practices. Indeed, the Soviet professional society of psychiatrists was in 1989 only provisionally readmitted to the World Psychiatric Association. See Teresa Smith with Thomas Oleszczuk, No Asylum: State Psychiatric Repression in the Former USSR (New York: New York University Press, 1996), 28.

43 For a detailed description of the history of Soviet theories of schizophrenia, see Martin A. Miller, "The Theory and Practice of Psychiatry in the Soviet Union," in Psychiatry 48 (February 1985): 16.

44 Smith and Oleszczuk, No Asylum, 4-5.

45 See Mee, Internment, 6-10 on the famous case of Major-General Petr Grigorenko. See also Smith and Oleszczuk, No Asylum, 7. 
of insanity. Psychiatric diagnosis by George Orwell. Not really good public relations at all.

It bears repeating that the madhouse-or the threat of it-was a real fact of Soviet life, a central part of the brutal treatment of individuals during the 1960s and '70s and even '80s. While it is fascinating to explore literary uses of the madhouse, we should always keep in mind that these were real institutions, doing real and barbaric things to real and broken people. The two so-called special psychiatric hospitals in Leningrad and Kazan each had a capacity for as many as one thousand patients, and we may never know just how many patients were "treated" throughout the system during the worst years of psychiatric repression. As Smith cautions, in Soviet Russia it was "no secret to anyone that you can have schizophrenia without schizophrenia." 46 Given the practices of Soviet psychiatry, depictions of the madhouse and Soviet psychiatrists such as we find in Makanin seem more like reportage than caricature.

The psychiatric hospital has acted as a potent metaphor for a number of cultures-after all, Ken Kesey's 1962 One Flew over the Cuckoo's Nest investigated similar ideas and conditions as we see in the Russian wards. The parallel of institution and restrictive regime is not uniquely Soviet. But when Tom Stoppard set his 1978 play Every Good Boy Deserves Favor in an asylum, he chose to set that asylum in Brezhnev's Russia, not in America or Britain. ${ }^{47}$ Issues of psychiatric repression were widely publicized by concerned humanists in the West in the 1970s, and they plagued Russians trying to figure out how to live and make choices in a collectivist, coercive state.

46 Smith and Oleszczuk, 1, quoting V. M. Morozov from Andre Koppers, A Biographical Dictionary on the Political Abuse of Psychiatry in the USSR (Amsterdam: International Association on the Political Use of Psychiatry, 1990), 36. Smith also suggests that post-Soviet society will continue to turn to psychiatrists for aid with problems of state, unless new standards of professional conduct are developed to counter habitual connections between medicine and politics (Smith and Oleszczuk, 199).

47 The details of Stoppard's play, down to the address of the special psychiatric hospital in Leningrad in which his hero is interred, seem to be culled directly from human rights reports of the 1970s, including the samizdat newsletter Chronicle of Current Events. In fact the play is based on Vladimir Bukovsky's memoirs, To Build a Castle: My Life as a Dissenter, trans. Michael Scammell (New York: Viking, 1978). See Stoppard, Every Good Boy Deserves Favor and Professional Foul (New York: Grove Press, 1978). A Russian review of Stoppard's Arcadia fifteen years ago noted that none of Stoppard's "dissident" plays, including Every Good Boy, had been translated into Russian. The reason given was that "political theater is out of fashion." See Otrazhenie nastoiashchego, Novyi mir 9: 657 (1996): 216. 
It is no accident that Makanin revived those concerns in contemporary post-Soviet fiction. ${ }^{48}$ While the history of the Russian asylum and the history of Russian madness are surely tied to a larger history of these questions in the West, Underground, or a Hero of Our Time serves to remind us of the particularly Russian way in which the issues resonate. Under conditions of punitive psychiatry, issues of power and language overlap with problems of psychiatric "care." For Makanin, truth is historically conditioned, and the power wielded by authorities-whether military hierarchies, police, or medical doctors-called out to be analyzed. The medical repression of the "I" in the service of the "we" deserved its own fictional treatment.

In the novel Underground, or a Hero of Our Time, the author foregrounds the deeply conscious, indeed self-conscious, nature of his connection to the Russian past and to Russian literary history, and in so doing he also highlights the question of the hero in history. Both Dostoevsky and Lermontov are present: Makanin has written a new version of Notes from Underground, with a new hero for a new time. The novel's epigraph comes from Lermontov's novel A Hero of Our Time (1840): "The hero ... is a portrait, but not of one man: it is a portrait compiled from the sins of our entire generation in its fullest development." As Lermontov did for the late Romantic era, Makanin was trying to identify what kind of hero (or heroes) lived in fin de siècle postSoviet Russia and to parse the meaning of "heroic" for the era.

Beyond the title, the novel makes thickly layered references to other works within the Russian literary canon. Makanin recalls, overtly or allusively, Saltykov-Shchedrin, Chekhov, Olesha, Pasternak, and Venedikt Erofeev, along with Dostoevsky, Lermontov, and many others. In fact, his hero Petrovich resembles no one more than Venichka Erofeev, both in life and in Erofeev's novel Moscow to Petushki (first publication 1973): often drunk, but just as often uttering philosophical truths, Petrovich loves to ride the Moscow Metro just as the fictional Venichka rode the suburban electric trains. ${ }^{49}$ With these referential devices, the author is writing his novel into the history of

48 In the United States, Stoppard's play, with Andre Previn's original score, was revived in November 2002 by the Wilma Theater and the Philadelphia Orchestra. The Czech directors of the Wilma, Blanka and Jiri Zizka, are old friends and fans of Stoppard's and frequently stage his work.

49 Scholars have also suggested a similarity to the sculptor Mikhail Shemiakin. See Aida Khachaturian, Roman V.S. Makanina Andegraund, ili geroi nashego vremeni: Homo Urbanis v pole 'Usredneniia' (Tallinn: PhD diss., Tallinn University, 2006), 124, note 71. 
Russian literature, with its "accursed questions" and its social agenda of helping the individual find his way within the collective.

The novel also builds on the rich Russian tradition of literary madness. In his study of Rabelais, Mikhail Bakhtin brought the analysis of literary madness back to the ancient ideas of Menippean satire, which when filtered through the lens of Romanticism rendered insanity as both a place of individual refuge and the source of individual revelation. Bakhtin went on to note the deep connection between freedom of speech and expression and the freedom of the spirit made possible through madness. Since neither was tolerated within Russian or Soviet culture, the possibilities offered by madness were particularly charged. The mad individual in the Russian tradition has always been an independent thinker. Perhaps his madness was precisely in his lack of respect for authority and his search for asylum, and inspiration, beyond the reach of civil society. ${ }^{50}$

This Menippean madman, flirting with freedom and death, can be found throughout Russian literature and history. Nineteenth-century philosopher Peter Chaadaev, mentioned in virtually every book on Russian psychiatry, ranks as the first prominent victim of punitive psychiatry. ${ }^{51}$ Literary heroes bristled on the pages of nineteenth-century Romantic literature, from Griboedov's Chatsky-misunderstood and frustrated by Moscow society-to the impoverished heroes of Gogol and Dostoevsky, to Lermontov's Pechorin, perhaps not mad, but certainly alienated and bitter. Beaten down by byt, these characters were not accepting of the norm but rather acted out their opposition to society's norms through pointed remarks, affronted behavior, drunken scenes, and even murder, exempting themselves from the standards of social behavior and claiming the freedom to act as they chose.

50 Citing Lucian's "Dialogues" - "Independence, every inch of him: he cares for no one. 'Tis Menippus!"-Bakhtin writes, "Let us stress in this Lucianic image of the laughing Menippus the relation of laughter to the underworld and to death, to the freedom of spirit, and to the freedom of speech" (Rabelais and his World, trans. by Helene Iswolsky [Cambridge, MA: MIT Press, 1968], 70). In Makanin, the "underworld" receives new metaphoric realization, but the principle of the relationship between independence, death, and freedom remains the same.

51 In fact, psychiatric diagnosis as a political instrument has a much longer history in Russia, dating back to eighteenth-century rationalist philosophy as absorbed by Russian rulers from Peter the Great to Catherine the Great. See Ilya Vinitsky, "A Cheerful Empress and her Gloomy Critics," Madness and the Mad in Russian Culture, ed. Brintlinger and Vinitsky (Toronto: University of Toronto Press, 2007), 25-45. For further discussion of the treatment and representation of the insane in Russia, see the entire volume. 
But whatever freedoms madness might bring to individuals, there was nothing of refuge about the institutional context of Russian madness. Both Gogol and Chekhov portrayed the asylum as a place of torture and betrayal. The larger chronotope of the repressive state institution, whether hospital or prison, continues to appear throughout modern Russian literature, from Dostoevsky and his Notes from the House of the Dead to Chekhov's "Ward No. 6," Solzhenitsyn's One Day and Cancer Ward, even Liudmila Petrushevskaia's The Time: Night. Each of these narratives uses the prison or the medical and psychiatric ward to force confrontations, to strip characters of their external differences, to reveal and explore their essential humanity, their strengths and weaknesses. These texts, many of them part of the realist tradition, depicted the asylum as a social microcosm. Others, such as Bulgakov's Master and Margarita, returned to the topos of asylum as refuge, and the Master finds a modicum of peace in Dr. Stravinsky's psychiatric clinic, far from the insanity of 1930s Moscow life.

Makanin draws freely from these literary and cultural traditions of madness, not distinguishing particularly between the paradigms of refuge and torture when concocting his postmodern melange of references. Each of the heroes explores the Menippean promises of madness, without ever quite fully realizing them. In Makanin's work, the psychiatric hospital is a refuge. Even though conditions in his hospital are abysmal and the orderlies are sadistic, ultimately the stark environment, like a stripped-down version of outer society, forces the hero Petrovich to confront the most basic of human needs-the need for empathy.

Upon first ending up in the madhouse, Makanin's Petrovich reminds himself that "the loony bin [psikhushka] is a piece of the state" and thus very similar to a police station or a prison (Andegraund, 343). Thus Makanin's psychiatric space is reminiscent of Chekhov's in "Ward No. 6"-a space of ultimate oppression, where the few rights of the individual which exist in everyday society have been abrogated. But Makanin gives his hero an individual quest that ends in almost optimistic success; in that absence of rights, Petrovich takes back his own humanity through an act of empathy and thus benefits from the oppression around him.

By the 1990s, such optimism was possible. If Dovlatov's characters sought solace and forgetfulness in alcohol and irony, Makanin took the historical circumstances of Soviet punitive psychiatry and showed the contrast between their practice in the 1970s and what the madhouse chronotope might reveal 
two decades later. In the novel, the path to the hospital leads backward in time to a more heroic age of overt struggle with clearly defined totalitarian enemies, whose eclipse in the post-Soviet era the hero paradoxically mourns. Beyond Brezhnev, beyond socialist realism, beyond the ideological hierarchies of Soviet society, Makanin's heroes must search for their own enemies without and within. The historical complexities confronted by the characters set them adrift in contemporary life, and their search for a mooring leads them to lunacy. As Makanin clearly shows, there is nothing Romantic about madness.

Let me now pull the lens back, to ask briefly how Makanin's novel reflects the experiences of the Soviet "man of the '60s." In Underground, or a Hero of Our Time, Makanin used the psychiatric hospital as a funhouse mirror on civil society in order to question and explore Soviet ideas about and experiences of the hero-the writer, the artist, the poet, the creative individual-and to begin to place those experiences within a post-Soviet context. In the process he resurrected Russian and Soviet literary experiences and characters-whether from the nineteenth century or the Brezhnev era of underground culture. He also reexamined those cultural moments, their cultural representatives, and the Soviet experiment of seventy years' duration-when being in the "andegraund" really meant something. This novel recalls a time of true opposition in the Soviet Union, when, as Philip Roth once said, nothing was possible, and everything mattered.

No apologist for the Soviet regime, Makanin was not using this novel as a simple act of nostalgia for the bad old days when it was easy to identify heroes and villains. Instead, the novel struck at the heart of the Russian intelligentsia's post-Soviet dilemma. Makanin was not celebrating the restrictive regimes of Khrushchev, Brezhnev, etc., and the crippled psyches of the Soviet population of those years.

Nonetheless, he and his compatriots are without doubt products of that history and that system. Just as in the pre-1917 era, when the intelligentsia struggled with tsarist censorship and repression, the Soviet-era Russian intelligentsia grew dependent on their own struggle with the even more controlling and interventionist totalitarian government. After the collapse of that government, the intelligentsia too lost its mooring. Having hoped and fought for the end of socialism and the Socialist state, they became confused as to what exactly their victory meant. They had won the Cold War, but were they heroes? 
By placing the madhouse at the center of this novel, Makanin confronted a central chronotope in nineteenth- and twentieth-century Russian history. In that confrontation, he recognized that while that history is horrible, it is the only history upon which he can draw. In the end, it may not be a history to celebrate, but it is his history. In that sense, writers at the end of the twentieth century resembled the writers of Russia after the Revolution: sifting through the debris of Russian history, they were searching for that which they could use to understand better their present moment. Could the individual find a path outside of the collective culture? What would become of the underground when the repressive agents were themselves repressed?

Makanin created his characters against the backdrop of the very strong tradition of the protagonist-centered Russian novel-from Gogol's Poprishchin to Lermontov's Pechorin, Turgenev's Bazarov, Rudin, etc., and Dostoevsky's Raskolnikov in the nineteenth century, and Chapaev (the socialist realist positive hero), Zhivago, Venichka, and so on in the twentieth. Whether in wartime or not, each of these heroes of the literary past confronted the problems of his own time, but by the end of the twentieth century with the collapse of the imperial mind-set of both tsarist Russia and its Soviet successor state, Makanin's protagonists were lost in their own societies. Makanin's Petrovich - a flawed dissident hero to be sure, but the only one capable of functioning in the post-Soviet world-found the answer to Russian and Soviet historical dilemmas in the actions of a true madman, his own brother Venya.

At the end of Underground, in a section entitled "One Day in the Life of Venedikt Petrovich" (an obvious reference to Solzhenitsyn's One Day in the Life of Ivan Denisovich), Petrovich brings Venya out of the asylum for a day of celebration. It seems that one or two of Venya's paintings have been published in a German art book, and to commemorate this event, Venya gets a twenty-four-hour furlough from the hospital. During this day, Petrovich tries to offer Venya everything the madman has been missing in his decades of asylum life: fame, friendship, women (what Petrovich calls "my contribution to his therapy"), material goods, homemade food, and tea. Venya, of course, decides that he does not want to go back to the madhouse, just as his psychological ability to function is nearing its end. Scared by Venya's increasingly erratic behavior, Petrovich gives him a tablet the doctor prescribed for just such an emergency, and as it begins to take effect, he says, "I began to lose my brother" (Andegraund, 540, 551). 
But even in his drug-induced psychological absence, Venya maintains a certain level of self-awareness, and this is the lesson he teaches his brother Petrovich. As Petrovich tries to drag Venya to the metro station, Venya pronounces two words: "I myself." I'll do it myself, he says, thus negating Petrovich's idea of what the state had done to Venya; while it may be true that Soviet psychiatric practices destroyed Venya and left him a childlike psychological cripple, Venya still maintains a kind of independence. Arriving at the asylum, he says again to the orderlies, "Don't push me, I [will go] myself." Petrovich hears this "I myself" through the silence of his own post-Brezhnev-era existence and understands that these are the words that he has been waiting to hear, the answer to his own questions in life:

And [ Venya] even straightened up, proud for this one moment-a Russian genius, beaten down, humiliated, pushed around, in his own shit, and yet don't push, I'll get there, I myself! $!^{52}$

Venya may need the madhouse, the only place where he can live after the Soviet psychiatric abuse visited upon his psyche, but he remains an artist and an independent soul. And having recognized the value and worth of this independence, the other hero, Petrovich, may find a way to function outside the madhouse as well. ${ }^{53}$

Makanin used his writer, Petrovich, along with the genius brother Venya, to describe the underground, to indict the system that forced it into existence, and to explore the meaning of both in a post-Soviet context. The madhouse functions as the main chronotope, as the plot circles back to it and to the protagonist's double: the better, wittier, purer brother on the inside. But the madhouse also functions to cleanse Petrovich of murder. Like Dostoevsky's

52 Makanin, Andegraund, 555, 556. Tim Sergay sees in this line a reference to the murdered priest Alexander Men, whose last words are purported to be "ia sam." Personal communication.

53 G. S. Smith reads Petrovich as a "violent anti-social hero" and sees a "solipsistic sense of personal identity" as his central core (Smith, "On the Page," 457). He finds Venya's "ia sam" to be a mere "pathetic insistence on doing things for himself" (Smith, "On the Page," 457 n. 44). In contrast, I argue that Petrovich learns two lessons in the madhouse. Petrovich discovers that the isolation that comes with murder, with transgression, can be overcome through human empathy; he also sees Venya's independence, his "ia sam," as the word he has been waiting for, the clue to reentering a creative state that, perhaps, gives the reader this very novel. 
Raskolnikov over a hundred years earlier, he has undergone an almost religious rebirth. After committing that most transgressive of acts, the taking of another's life, Petrovich finds a way to reenter the community of humankind. And his fellow post-Soviet citizens who welcome him back in turn recover some of their own humanity by discovering forgiveness. Makanin used the madhouse as a place where people could work out a sense of their larger humanness. It is almost cliched to repeat that Soviet society and the constant state of war stripped its citizens of much of their humanity. Makanin's novel underscored how complicated and problematic it became to restore that humanity in the post-Soviet era.

Joseph Brodsky commented that readers could sense in Dovlatov's tone a refusal to be victimized. That stance-of the individual who chooses his own fate, not willing to have his life scripted by the authorities or anyone elsewas one that Brodsky knew well from personal experience, including his own experience in psychiatric institutions. Brodsky went on to say:

Serezha belonged to a generation which took the idea of individualism and the principle of the autonomy of human existence more seriously than had ever been the case before anywhere. I can speak about this authoritatively since I have the honor-the great and sad honor-to belong to this generation myself. ${ }^{54}$

This is the generation about which Makanin wrote his memoir, and that stance of the autonomous individual was the same stance that Makanin's Venya, despite the serious damage that has been inflicted on him, managed to take at the end of the novel. ${ }^{55}$

Brodsky and Dovlatov were born at almost the same moment to Leningrad families-one just before the siege and one during evacuation-and both ended up ejected from their homeland. They, like Makanin and even

54 Joseph Brodsky, "O Serezhe Dovlatove: 'Mir urodliv, i liudi grustny"' in Dovlatov, Sobranie prozy, 3: 360.

55 On Brodsky and the psychiatric hospital, see especially Lev Loseff, "On Hostile Ground: Madness and Madhouse in Joseph Brodsky's 'Gorbunov and Gorchakov,' in Madness and the Mad, 90-104. 
more so his hero Petrovich, were men of the sixties. In one of his autobiographical essays, Brodsky describes his set of friends, who even if they made it through their higher education were unable to perform the "lip service" required to work in the system:

We ended up doing odd jobs, menial or editorial—or something mindless, like carving tombstone inscriptions, drafting blueprints, translating technical texts, accounting, bookbinding, developing X-rays. ${ }^{56}$

They represent that generation of dropouts sometimes known as the "boiler room" generation; unable to stand the militarized Soviet institutions, almost allergic to marching in formation, they dropped out of school and university and took menial jobs-or wrote about characters who did. In another essay, Brodsky explained why he hated even his school uniform:

That uniform, too, was semi-military: tunic, belt with a buckle, matching trousers, a cap with a lacquered visor. The earlier one starts to think of himself as a soldier, the better it is for the system. That was fine with me, and yet I resented the color, which suggested the infantry or, worse still, the police. ${ }^{57}$

The classroom, the infantry, the police, the prison, and finally the asylum-at some level, for this generation of post-heroic Russian men, these Soviet institutions all merged together seamlessly. In the age of Brezhnev, when all aspects of life from childhood on were regimented and disciplined, and when the threat of physical and psychological violence always loomed, heroism in the old sense was impossible. Preserving one's own integrity, whether as a drunk in Dovlatov's fiction or in a madhouse in Makanin's, was the best one could aspire to.

56 Joseph Brodsky, "Less than One," in Less than One: Selected Essays (New York: Farrar, Straus, Giroux, 1986), 29.

57 Brodsky, "In a Room and a Half," in Less than One, 468. 